\title{
Social Relations of Working Mothers in The Work- Family Conflict Within Indigenous Psychology Approaches
}

\author{
$1^{\text {st }}$ Triana Noor Edwina Dewayani \\ Soeharto* \\ Faculty of Psychology Universitas \\ Mercu Buana Yogyakarta \\ Yogyakarta, Indonesia \\ winasoeharto@gmail.com
}

\author{
$2^{\text {nd }}$ Muhammad Wahyu Kuncoro \\ Faculty of Psychology \\ Universitas Mercu Buana Yogyakarta \\ Yogyakarta, Indonesia \\ wahyu@mercubuana- yogya.ac.id
}

\author{
$3^{\text {rd }}$ Sowanya Ardi Prahara \\ Faculty of Psychology \\ Universitas Mercu Buana Yogyakarta \\ Yogyakarta, Indonesia \\ sowanya_hara@yahoo.com
}

\begin{abstract}
This study aims to explore social relations in the family from the perspective of working mothers who experience work-family conflict based on an indigenous psychology approach. This research was conducted in the Special Region of Yogyakarta. The characteristics of the research subjects are wives who identify themselves as Javanese who have children under 12 years who live with their husbands and work as professionals. Research data collection used open-ended questionnaire instruments given to 240 research subjects. The data collected were analyzed using thematic analysis techniques to obtain a picture of social relations in the family from the perspective of working mothers who experienced work-family conflicts. The research findings show that some important aspects are expected to exist in a family according to the working wives. An important point that gets the most responses is mutual understanding, receive mutual advantages / disadvantages, mutually open, communication, mutual trust, help each other, mutual respect, love each other, mutual sharing. Good relations that are established in the family also determine whether a work-family conflict experienced by working mothers will be resolved or not. The results of this study will be used as a basis for developing measurement tools for social relations in families of working mothers who experience work-family conflicts.
\end{abstract}

Keywords: family social relations; working mother; workfamily conflict

\section{INTRODUCTION}

Based on sex, there are differences in Labor Force Participation Rate (LFPR) between men and women. In February 2019, the male LFPR was 83.18 percent and the female LFPR was only 55.50 percent. Compared to the previous condition, male and female TPAK increased by 0.17 percentage points and 0.06 percentage points respectively [1]. Of the total population employed in February 2019, most of the main occupational status were laborers / employees (39.13 percent). Based on this identification, then in February 2019 as many as 55.28 million people (42.73 percent) of the population worked in formal activities. Formal workers included the status of doing business with the assistance of permanent workers and laborers / employees [1].

The increasingly widespread role of women in the public sector will cause problems in women. If women who work, marry and have children, help to make a living in the public sector but the domestic burden is not reduced, then the responsibilities of these women become multiple [2]. The expected role of women has not changed much. Working women are still expected to be responsible for household chores. Working women get a little help from their husbands, who consider their husband's main task in the family limited to making a living and protecting the family. The complexity of the problems regarding the role of women working in the public sector is related to cultural structures.

The culture is still very thick and colors various aspects of life and community structure and creates gender inequalities. Inequality in the roles of women and men makes women who work more experience work-family conflicts. a meta-analysis conducted by [3] explains that women experience work-family conflicts because men's work in the family is more flexible, whereas women's work is more routine, for example responsibility for children especially under 12 years of age.

Work and family conflicts are conflicts between roles, conflicts arise when roles in work and family demand to be fulfilled, fulfilling one role will complicate the fulfillment of other roles [4] [2]. According to [4], factors in work will affect family life (conflict between work-family) and conversely factors in family will affect work (family- work conflict). Good relations that are established in the family also determine whether a work-family conflict experienced by working mothers will be resolved or not.

This study aims to explore social relations in the family from the perspective of working mothers who experience work-family conflict based on an indigenous psychology approach. This research was built based on an understanding of humans in the local context (Indigenous) so that the research results obtained are truly pure understanding of Indonesian people can be applied according to the context of Indonesian culture. According to Berrsc heid and Ammazzalorso [5], a relationship is a relationship between individuals who are interdependent behavior so that changes in behavior that occur on one party will tend to provide changes to other parties. Good relations that are established in the family also determine whether a work-family conflict experienced by working mothers will be resolved or not. 


\section{METHODS}

This research was conducted in the Special Region of Yogyakarta. Characteristics of the research subjects are wives who identify themselves as ethnic Javanese with children under 12 years who live with their husbands, and work as professionals. Research data collection using the instrument open-ended questionnaire given to 240 research subjects. Survey Method on research subjects was conducted to explore forms of social relations the data collected was analyzed using thematic analysis techniques to obtain a picture of social relations in the family from the perspective of working mothers who experience workfamily conflicts.

\section{RESULTS AND DISCUSSIONS}

Distribution of participant responses about expected good relations in the family. Quantitative data analysis shows that the majority of participants stated that relationships based on mutual understanding are very important $(24.5 \%)$, the next is mutual acceptance of strengths and weaknesses of partners (14.7\%), and sharing is a response at least $3.7 \%$. The total number of participants who have responded in this study was 240 , with a total response of 572 . The total distribution of responses based on the categories obtained can be seen in Table 1 below

TABLE I. DISTRIBUTION OF PARTICIPANT RESPONSES ON SOCIAL RELATIONS IN FAMILIES

\begin{tabular}{|l|c|c|}
\hline \multicolumn{1}{|c|}{ Category } & $\begin{array}{c}\text { Number of } \\
\text { Response }\end{array}$ & Percent \\
\hline 1. Mutual understanding & 140 & 24,5 \\
2. Receive mutual & 84 & 14,7 \\
$\quad$ advantages/ & & \\
$\quad$ disadvantages & 76 & 13,3 \\
3. Mutually open & 71 & 12,4 \\
4. Communication & 60 & 10,5 \\
5. Mutual trust & 50 & 8,7 \\
6. Help each other & 40 & 7,0 \\
7. Mutual respect & 30 & 5,2 \\
8. Love each other & 21 & 3,7 \\
9. Mutual sharing & 572 & 100 \\
\hline Total of respone & & \\
\hline
\end{tabular}

Most participants said that a good relationship in the family was marked by mutual understanding with a partner. As working mothers have to divide their time and activities to work outside the home and also do chores in the family. Couples who can understand the condition of the wife are felt to be able to support the wife to undergo this role. Couples are expected to understand each other's busy lives, can complement, and complement each other, easy to forgive and the desire to maintain good relations.

The consequence of working mothers is the lack of time for the family, so that more or less there are household tasks that cannot be completed properly. Participants really hope that the couple can accept these limitations by not demanding excessively when doing their duties both as working mothers and as wives.

Working mothers tend to spend more time to complete their work, so the time for family is reduced, especially with their husbands. Because of this openness becomes important for participants, couples are expected to show honesty and openness in various ways.
Communication becomes an important aspect that is expected in couples, participants expect a willingness to maintain good communication continuously, take time to communicate and be able to talk about anything.

The next aspect is mutual trust in the couple. Trust is the main foundation in developing relationships in the family and maintaining each other so that trust is maintained.

Hope to be able to help each other also becomes important for participants, couples are expected to be willing to aid in any condition and are willing to share tasks, especially at home jobs.

Participants also assessed the importance of mutual respect for couples. For working mothers, appreciation from their husbands for what their wives have done is thought to create a good relationship. The next important aspect is giving mutual attention and willingness to share responsibilities in the family and as partners to listen to stories and complaints.

\section{CONCLUSION}

Based on the results and discussion in this study, it can be concluded that there are important aspects that are expected to exist in family relations according to working mothers who experience work-family conflict, namely mutual understanding, receive mutual advantages/ disadvantages, mutually open, communication, mutual trust, help each other, mutual respect, love each other, mutual sharing.

These important aspects need to be created and developed in a family where there is a mother who in addition to being a household manager also has the responsibility to work outside the home.

\section{REFERENCES}

[1] BPS, Berita resmi statistik: Keadaan ketenagakerjaan Indonesia. 2019.

[2] M. N. Noor, "Work-family conflict, locus of control, and women`s well-being: Tests of altenative pathways," J. Soc. Psychol., vol. 142, no. 5, pp. 645-662, 2002.

[3] M. T. Ford, B. A. Heinen, and K. L. Langkamer, "Work and family satisfaction and conflict: A meta-analysis of cross-domain relations," J. Appl. Psychol., vol. 92, no. 1, pp. 57-80, 2007.

[4] Z. Aycan and M. Eskin, "Relative contributions of childcare, spousal support, and organizational support in reducing work-family conflict for men and women: The case of Turkey," Sex Roles, vol. 53, no. 7/8, pp. 453-471, 2005.

[5] J. E. Yulianto and Faturochman, "Interdependensi pada relasi perkawinan," in Faturochman \& Nurjaman, T.A. Psikologi Relasi Sosial, Yogyakarta: Pustaka Pelajar, 2018. 